\title{
Akt/Protein Kinase B Is Required for Lymphatic Network Formation, Remodeling, and Valve Development
}

\author{
Fei Zhou, ${ }^{*}$ Zai Chang, ${ }^{\dagger}$ Luqing Zhang, ${ }^{*}$ \\ Young-Kwon Hong, ${ }^{\ddagger}$ Bin Shen, ${ }^{*}$ Bo Wang, ${ }^{*}$ \\ Fan Zhang, ${ }^{\S}$ Guangming Lu, ${ }^{\S}$ Denis Tvorogov, \\ Kari Alitalo," Brian A. Hemmings," \\ Zhongzhou Yang, ${ }^{\dagger}$ and Yulong $\mathrm{He}^{*}$ \\ From the Laboratory of Vascular and Cancer Biology,* and the \\ Laboratory of Heart and Disease Model, ${ }^{\dagger}$ MOE (Ministry of \\ Education) Key Laboratory for Model Animal and Disease Study, \\ Model Animal Research Institute, Nanjing University, Nanjing, \\ China; the Departments of Surgery and Biochemistry and \\ Molecular Biology, ${ }^{\ddagger}$ Norris Comprehensive Cancer Center, Keck \\ School of Medicine, University of Southern California, Los \\ Angeles, California; the Department of Medical Imaging, \\ Nanjing Jinling Hospital, Clinical School of Medical College, \\ Nanjing University, Nanjing, China; the Molecular/Cancer \\ Biology Laboratory, "T the Department of Pathology, Haartman \\ Institute and Ludwig Institute for Cancer Research, Biomedicum \\ Helsinki, Helsinki University Central Hospital, University of \\ Helsinki, Helsinki, Finland; and the Friedrich Miescher Institute \\ for Biomedical Research," Basel, Switzerland
}

\begin{abstract}
Akt-mediated signaling plays an important role in blood vascular development. In this study, we investigated the role of Akt in lymphatic growth using Akt-deficient mice. First, we found that lymphangiogenesis occurred in $\mathrm{Akt1} 1^{-/-}, \mathrm{Akt}^{-/-}$, and $\mathrm{Akt} 3^{-/-}$ mice. However, both the diameter and endothelial cell number of lymphatic capillaries were significantly less in $\mathrm{Akt1}^{-/-}$mice than in wild-type control mice, whereas there was only a slight change in $A k t 2^{-/-}$and $A k t 3^{-/-}$mice. Second, valves present in the small collecting lymphatics in the superficial dermal layer of the ear skin were rarely observed in $A k t 1^{-/-}$mice, although these valves could be detected in the large collecting lymphatics in the deep layer of the skin tissues. A fluorescence microlymphangiography assay showed that the skin lymphatic network in $\mathrm{Akt1}^{-/-}$mice was functional but abnormal as shown by fluorescein isothiocyanate-dextran draining. There was an uncharacteristic enlargement of collecting lymphatic vessels, and further analysis showed
\end{abstract}

\begin{abstract}
that smooth muscle cell coverage of collecting lymphatic vessels became much more sparse in Akt1deficient mice than in wild-type control animals. Finally, we showed that lymphatic vessels were detected in compound $A k t$-null mice and that lymphangiogenesis could be induced by vascular endothelial growth factor-C delivered via adenoviral vectors in adult mice lacking $A k t 1$. These results indicate that despite the compensatory roles of other Akt isoforms, Akt1 is more critically required during lymphatic development. (Am J Pathol 2010, 177:2124-2133; DOI: 10.2353/ajpath.2010.091301)
\end{abstract}

The lymphatic system provides an important conduit for the maintenance of tissue fluid homeostasis and transport of macromolecules as well as immune cells into the blood circulation and is also implicated in inflammation and tumor metastasis. ${ }^{1-6}$ During the last decade, extensive studies have been carried out in the field of lymphatic research, which have resulted in great insights into the molecular network underlying lymphatic development. Prox1, a homeobox transcription factor, has been shown to be a fate-determining factor for lymphatic endothelial cell differentiation, ${ }^{7,8}$ and its expression is controlled by Sox $18 .{ }^{9}$ Activation of vascular endothelial growth factor receptor-3 signaling by its ligand vascular

Supported by the National Natural Science Foundation of China (grants 30771069, 30671038, and 30930028), the National Key Basic Research Program of China (grant 2006CB943502), and the Ministry of Education of China (NCET: Program for New Century Excellent Talents in University).

F.Z., Z.C., and L.Z. contributed equally to this work.

Accepted for publication June 16, 2010

Supplemental material for this article can be found on http://ajp. amjpathol.org

Address reprint requests to Yulong He, Ph.D., Laboratory of Vascular and Cancer Biology, MOE Key Laboratory for Model Animal and Disease Study, Model Animal Research Institute, Nanjing University, Nanjing, China; or Zhongzhou Yang, Ph.D., Laboratory of Heart and Disease Model, MOE Key Laboratory for Model Animal and Disease Study, Model Animal Research Institute, Nanjing University, Nanjing, China. E-mail: yhe20005@yahoo.com or yangzz@nicemice.cn. 
endothelial growth factor (VEGF)-C/-D plays crucial roles for lymphatic endothelial cell proliferation, migration, and survival during the formation of the lymphatic network. ${ }^{10,11}$ Various other genes have also been identified as participating in lymphatic development. ${ }^{2,5}$

The serine/threonine protein kinase Akt (also named PKB) acts as a major signal transducer downstream of phosphoinositide-3 kinase. ${ }^{12,13}$ Three isoforms of Akt exist in mammalian cells, including Akt1, Akt2, and Akt3, and are encoded by three separate genes, which have approximately $85 \%$ sequence identity. ${ }^{14}$ Akt can be activated by many angiogenic growth factors such as VEGF and angiopoietin-1, which are mediated by their corresponding receptor tyrosine kinases. ${ }^{15-18}$ It has been shown that VEGF-mediated activation of Akt is critical for vessel patterning in zebrafish ${ }^{19}$ and vascular development of the chorioallantois in chick embryos. ${ }^{20}$ Although Akt plays an important role in blood vascular development including cell survival and cell growth and differentiation by orchestrating a number of signaling pathways in endothelial cells, ${ }^{13,21}$ the contribution of each Akt isoform in this process has not been fully elucidated. A recent study has demonstrated that Akt1 is the predominant isoform in mouse blood vascular endothelial cells, and endothelial cell proliferation and migration in response to VEGF were impaired when Akt1 was deleted. ${ }^{22}$

So far, the role of Akt-mediated signaling in lymphatic development has been poorly understood. Mice homozygous for Pik3r1, which encodes p $85 \alpha$ as well as two smaller variants ( $555 \alpha$ and $p 50 \alpha$ ) acting as regulatory subunits of class $\mathrm{I}_{\mathrm{A}}$ phosphoinositide 3 -kinases, were shown to have chylous ascites accumulation into the abdomen after birth. ${ }^{23}$ Further investigation demonstrated that there was defective lymphatic development and valve formation in Pik3r1 ${ }^{-1-}$ mice. ${ }^{24}$ In this study, we further show that Akt can be activated on VEGF-C induction in primary lymphatic endothelial cells. Although lymphatic vessel growth occurred in the single Akt knockout mice $\left(A k t 1^{-\prime-}, A k t 2^{-\prime-}\right.$, or $\left.A k t 3^{-\prime-}\right)$, loss of Akt1 led to abnormal lymphatic development including the reduced lymphatic endothelial cell numbers and vessel size, defective valve development, and smooth muscle cell coverage of collecting lymphatics. This result indicates that Akt1 is the major isoform in mediating signals for lymphatic development.

\section{Materials and Methods}

\section{Knockout Models}

Akt1, Akt2, and Akt3 knockout mice were generated as described previously $y^{25-27}$ and backcrossed into the C57BL/6 background. All animal experiments were performed in accordance with the institutional guidelines of the Model Animal Research Institute of Nanjing University.

\section{Cell Culture}

$\mathrm{NCl}-\mathrm{H} 460$ cells were obtained from American Type Culture Collection (Manassas, VA) and were maintained in
RPMI 1640 (Sigma-Aldrich, St. Louis, MO) supplemented with $2 \mathrm{mmol} / \mathrm{L}$ L-glutamine, penicillin $(100 \mathrm{U} / \mathrm{ml})$, streptomycin $(100 \mu \mathrm{g} / \mathrm{ml})$, and $10 \%$ fetal calf serum (PromoCell, Heidelberg, Germany). Primary human lymphatic endothelial cells (hLECs) were isolated from human foreskin as described previously. ${ }^{28} \mathrm{hLECs}$ were cultured in $10 \mu \mathrm{g} / \mathrm{ml}$ fibronectin-coated plates with endothelial growth medium containing growth supplements from Promocell.

\section{Production of Recombinant Adenoviruses and in Vivo Delivery of VEGF-C Via Adenoviral Vector}

The cDNA encoding human VEGF-C was cloned into the transfer vector (pShuttle-IRES-EGFP) of the AdEasy vector system (Qbiogene, Carlsbad, CA). Recombinant adenoviruses (AdVEGF-C/GFP and AdGFP) were produced following the manufacturer's instruction. $\mathrm{NCl}-\mathrm{H} 460$ cells used for expression analysis were transduced with $\mathrm{Ad}$ VEGF-C/GFP or AdGFP (multiplicity of infection 50). Expression of VEGF-C was confirmed by Western blot analysis of the conditioned medium as described previously, ${ }^{29}$ and green fluorescent protein (GFP) expression by the examination under a fluorescence microscope.

Approximately $2 \times 10^{8}$ plaque-forming units of AdVEGFC/GFP or AdGFP control viruses were injected subcutaneously into mouse ears. Tissues were collected for histological analysis within 2 weeks after adenoviral transduction.

\section{Immunohistochemistry}

Antibodies used in this study included rabbit anti-mouse LYVE-1 (Abcam Inc., Cambridge, MA) or rat anti-mouse LYVE-1 (a kind gift from Dr. Gou Young Koh, KAIST, Daejeon, Republic of Korea), rabbit anti-human Prox1 (Abcam, and a kind gift from Dr. Tatiana V. Petrova, University of Lausanne, Lausanne, Switzerland), goat anti-mouse Integrin- $\alpha 9$ (R\&D Systems, Minneapolis, MN), rabbit anti-human phosphorylated endothelial nitric oxide synthase (eNOS) (Upstate Biotechnology, Charlottesville, VA), hamster anti-mouse platelet/endothelial cell adhesion molecule-1 (PECAM-1) (Millipore Corporation, Billerica, MA), or monoclonal rat anti-mouse PECAM-1 (PharMingen, San Diego, CA), and Cy3-conjugated mouse anti-mouse $\alpha$-smooth muscle actin (Sigma-Aldrich). For whole-mount staining of blood vascular and lymphatic vessels, tissues were fixed in $4 \%$ paraformaldehyde, blocked with $3 \%$ milk and $0.3 \%$ Triton X-100 in PBS, and incubated with antibodies against LYVE-1 and PECAM-1 overnight at $4^{\circ} \mathrm{C}$. Alexa 594-, Alexa 488-, or Cy5-conjugated secondary antibodies (Molecular Probes, Eugene, OR) were used for staining, and samples were then mounted with Vectashield (Vector Laboratories, Burlingame, CA) and analyzed with a Leica confocal microscope.

For staining of tissue sections, tissues were fixed in $4 \%$ paraformaldehyde overnight at $4^{\circ} \mathrm{C}$, and paraffin sections $(6 \mu \mathrm{m})$ were immunostained with antibodies as described above. The signals were amplified using the tyramide 
signal amplification system (PerkinElmer Life and Analytical Sciences, Waltham, MA). Peroxidase activity was developed using 3-amino-9-ethyl carbazole (Sigma-Aldrich), and sections were counterstained with hematoxylin before analysis. For staining of cryosections, tissues were fixed in $4 \%$ paraformaldehyde for 2 hours on ice, incubated in 20\% sucrose/PBS overnight and embedded in O.C.T. compound (Tissue-Tek, Sakura Finetek USA, Inc., Torrance, CA). Sections $(10 \mu \mathrm{m})$ were used for immunostaining as described above.

\section{Cell Proliferation Analysis}

Mice were injected with BrdU (0.1 mg/g b.wt., Sigma-Aldrich) 2 hours before sample collection. Skin tissues were collected and processed for histological analysis. 5-Bromo2'-deoxyuridine (BrdU) incorporation was detected using mouse anti-BrdU (Roche Diagnostics, Indianapolis, IN) antibody, followed by staining with Alexa 488-conjugated secondary antibody (Roche Diagnostics). Lymphatic endothelial cells were identified by immunostaining for Prox 1 as described above. BrdU ${ }^{+} /$Prox $^{+}{ }^{+}$cells were examined under a fluorescence microscope and quantified.

\section{Western Blot Analysis}

hLECs were starved overnight in serum-free basal medium and then were stimulated for 30 minutes with 100 $\mathrm{ng} / \mathrm{ml}$ recombinant human VEGF-C (R\&D Systems). Cells were lysed in the lysis buffer ( $1 \%$ Nonidet P-40, $20 \mathrm{mmol} / \mathrm{L}$ Tris- $\mathrm{HCl}$ [pH 7.5], $150 \mathrm{mmol} / \mathrm{L} \mathrm{NaCl}, 5 \mathrm{mmol} / \mathrm{L}$ EDTA, 2 $\mathrm{mmol} / \mathrm{L} \mathrm{Na} \mathrm{VO}_{4}, 100 \mu \mathrm{mol} / \mathrm{L}$ phenylmethylsulfonyl fluoride with proteinase inhibitor cocktail [Roche Diagnostics]) and cleared of particulate material by centrifugation. Total lysates were analyzed by SDS-polyacrylamide gel electrophoresis and blotted with antibodies against Akt or phospho-Akt (Cell Signaling Technology, Danvers, MA).

\section{Quantification of Lymphatic Diameter}

For the quantification of lymphatic capillary size in ear skin, eight images (with $\times 100$ magnification) representing different regions of whole ear skin (bottom side) were taken under a fluorescence microscope and kept constant for all of the samples. Five horizontal lines were evenly laid on the images, and the diameters of lymphatic vessels crossed with these lines were measured and analyzed using Image Pro Plus (MediaCybernetics, Inc., Bethesda, MD).

\section{Fluorescence Microlymphangiography}

The functionality of the lymphatic network in Akt-null mice was assayed by fluorescence microlymphangiography using fluorescein isothiocyanate (FITC)-conjugated dextran (FITC-dextran 2000, Sigma-Aldrich). FITC-dextran (2 $\mu l)$ was injected intradermally into mouse ears or tails. The lymphatic vessels were examined using a fluorescence dissection microscope (MZFLIII, Leica, Wetzlar, Germany).

\section{Statistics}

Statistical analyses were performed with the unpaired Student's $t$-test. All $P$ values are two-tailed.

\section{Results}

\section{Alteration of Lymphatic Capillary Size in Akt1 ${ }^{-1-}$ Mice}

To investigate the role of Akt in lymphatic development, we examined the skin sections from adult $A k t 1^{-1-}$, $A k t 2^{-1-}$, and $A k t 3^{-1-}$ and wild-type (WT) control mice by immunostaining for the lymphatic marker LYVE- $1 .{ }^{30} \mathrm{Com}-$ pared with the WT control (Figure 1A), in the single Akt gene knockout mice lymphatic vessels could be detected (Figure 1, B-D), and there was no obvious difference in lymphatic vessel number. However, whole-mount immunostaining with ear skin revealed that the diameter of capillary lymphatics in $A k t 1^{-/}$mice was significantly less than that of the WT control mice (Figure 1, E-H). The size of the lymphatic capillaries was quantified using Image-Pro Plus (MediaCybernetics, Inc.). As shown in Figure 11, the diameter of skin lymphatic capillaries in Akt $1^{-1-}$ mice was approximately half of that in WT mice. Lymphatic size was also slightly less in $A k t 2^{-/-}$and $\mathrm{Akt}^{-1-}$ mice than that of the wild-type control. Consistently, the change in lymphatic capillary size was also seen in internal organs such as the intestine of Akt1-null mice (Supplemental Figure 1, see http://ajp.amjpathol.org). We also examined blood vessels of skin in $A k t 1^{-/-}$mice by whole-mount immunostaining for pan-endothelial cell marker PECAM-1. As shown in Supplemental Figure 2 (see http://aip.amipathol.org), there was no obvious difference in blood vessel diameter between the $A k t 1^{-1-}$ and WT mice.

To find out the reason for the alteration of lymphatic vessel diameter in Akt1-null mice, we analyzed the lymphatic endothelial cell (LEC) number in skin lymphatics by immunostaining for LYVE-1 and Prox1 (Figure 2, A-F). Quantification of LEC number revealed that total LECs per grid was about half in lymphatic capillaries of Akt1null mice compared with that of control mice (Figure 2G). The difference remained the same after the normalization of LEC number by lymphatic length (LECs/per 100- $\mu \mathrm{m}$ lymphatic vessel) (Figure $2 \mathrm{H}$ ). We further examined lymphatic endothelial cell proliferation by BrdU labeling and immunostaining for Prox 1 with skin tissues at postnatal day 1 . There was only a small trend toward the decrease of the percentage of $\mathrm{BrdU}^{+}$lymphatic endothelial cells $\left(\mathrm{BrdU}^{+} / \mathrm{Prox}^{+}{ }^{+}\right)$in Akt1-null mice (Supplemental Figure 3, see http://ajp.amjpathol.org). Apoptotic lymphatic endothelial cells were also hardly observed by terminal deoxynucleotidyl transferase dUTP nick-end labeling staining in both WT and Akt1-null mice (data not shown). In addition, we analyzed the eNOS expression and its phosphorylation status in lymphatic vessels by immunostaining, and there was no obvious difference in the total eNOS (data not shown) and phosphorylated eNOS levels (Supplemental Figure 4, see http://ajp.amjpathol.org) between Akt1 deficient and control mice. 
A

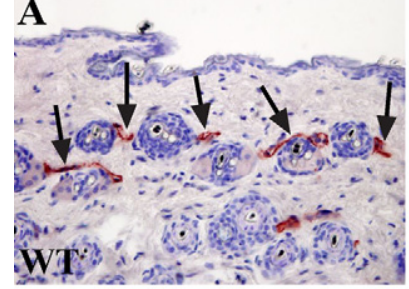

C
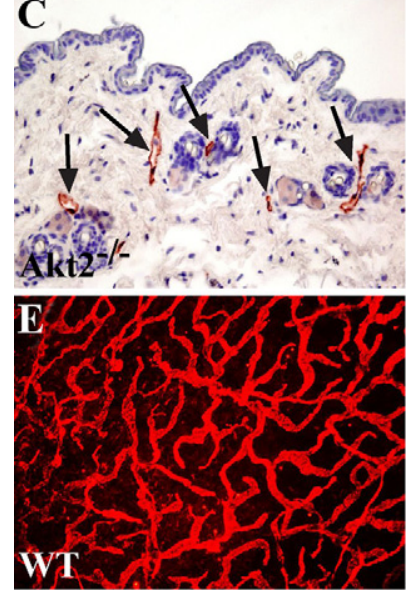

B
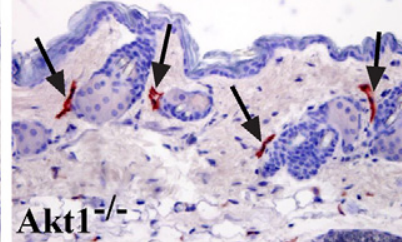

D
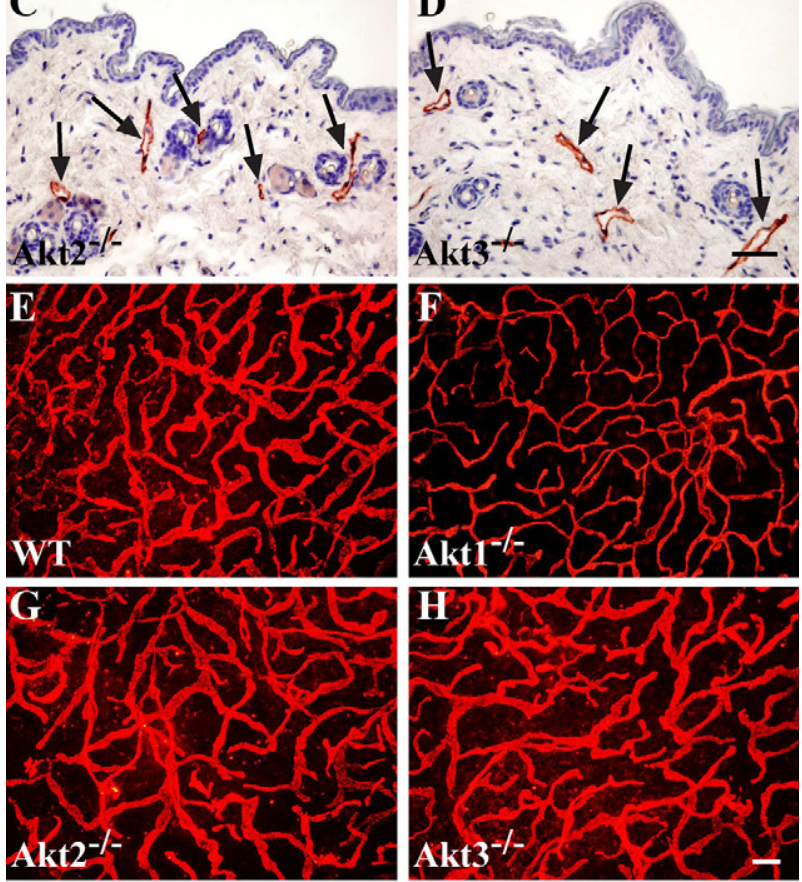

I

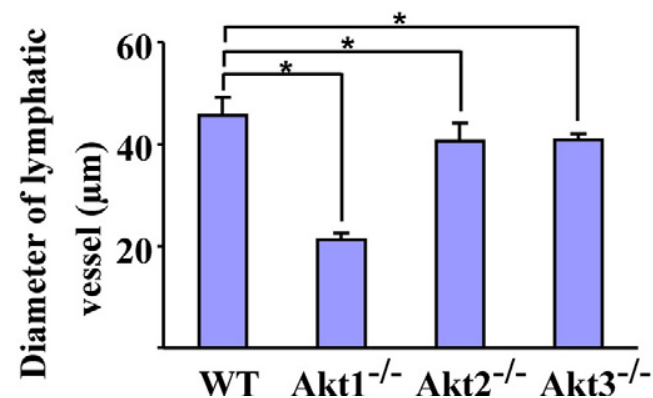

Figure 1. Histological analysis of lymphatic vessels in single Akt knockout mice. A-D: Immunohistochemical staining for LYVE-1 with skin sections of WT (A), $A k t 1^{-/-}$(B), Akt $2^{-/-}(\mathbf{C})$, and $A k t 3^{-/-}$mice (D). Arrows point to lymphatic vessels. E-H: Whole-mount staining for LYVE-1 with ear skins of WT (E), $A k t 1^{-/-}(\mathbf{F}), A k t 2^{-/-}(\mathbf{G})$, and $A k t 3^{-/-}$mice (H). I: Quantification of lymphatic vessel diameters from WT, $A k t 1^{-1-}, A k t 2^{-1-}$, and $A k t 3^{-1-}$ mice (WT: $45.7 \pm 3.5 \mu \mathrm{m} ; A k t 1^{-1}: 21.2 \pm 1.4 \mu \mathrm{m}, P<0.0001 ; A k t 2^{-1-}: 40.5 \pm$ $3.6 \mu \mathrm{m}, P=0.0295 ; \mathrm{Akt}^{-1-}: 40.8 \pm 1.2 \mu \mathrm{m}, P=0.0088$; mean $\pm \mathrm{SD} ; n=$ 6 for each group). ${ }^{*} P<0.05$. Scale bars: $50 \mu \mathrm{m}(\mathbf{D}) ; 200 \mu \mathrm{m}(\mathbf{H})$

\section{Lack of Valve Formation in Small Collecting Lymphatics of Akt1-Null Mice}

We further examined lymphatic valve formation in Akt1null mice. The bottom side of ear skin adjacent to cartilage contains mainly lymphatic capillaries and small collecting lymphatics, and large collecting lymphatics are present in the deep layer of tissues at the upper side of ear skin. Analysis of ear skin from wild-type mice by whole-mount immunostaining with PECAM-1 showed that
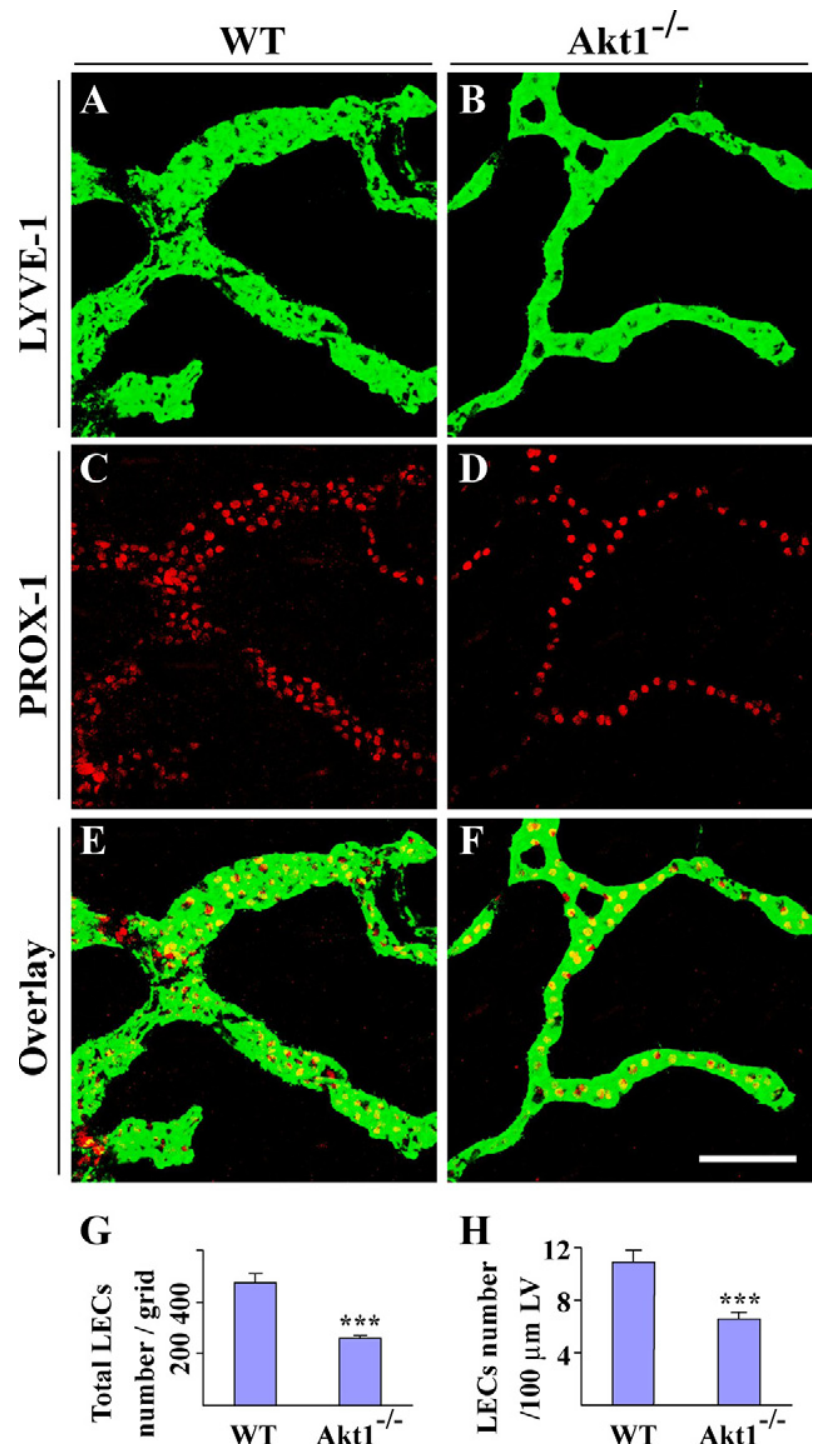

Figure 2. Fewer endothelial cell numbers in lymphatic capillaries of Akt $1^{-1-}$ mice. A-F: Whole-mount staining for LYVE-1 (green) and PROX1 (red) with ear skins of WT $(\mathbf{A}, \mathbf{C}$, and $\mathbf{E})$ and $A k t 1^{-1-}$ mice $(\mathbf{B}, \mathbf{D}$, and $\mathbf{F})$. G: Quantification of total LEC number in WT and $A k t 1^{-1-}$ mice (WT: $473.7 \pm$ 34.7 cells/grid; $A k t 1^{-/-}: 258.6 \pm 11.7$ cells/grid; mean \pm SD; $n=6$ for each group; $P<0.0001)$. H: Quantification of LEC numbers per $100-\mu \mathrm{m}$ lymphatic vessel (LV) in WT and $A k t 1^{-/-}$mice (WT: $11.0 \pm 0.9$ cells, $A k t 1^{-/-}: 6.6 \pm 0.5$ cells; mean $\pm \mathrm{SD} ; n=6$ for each group; $P<0.0001)$. ${ }^{* * * *} P<0.0001$. Scale bar: $100 \mu \mathrm{m}$.

lymphatic valves were strongly stained although lymphatic vessels were faintly positive for PECAM-1 (Figure $3, A, B, F$, and $G$, arrows). There was also sparse smooth muscle cell coverage with valve-containing small collecting lymphatics (Figure $3 \mathrm{C}$ ). Note that regions with smooth muscle cell (SMC) coverage in lymphatic vessels were negative for LYVE-1 staining (Figure 3, C-E, arrowheads). Interestingly the valves and smooth muscle cell coverage were rarely observed in lymphatic vessels in the corresponding area of $A k t 1^{-1-}$ mice (Figure 3, F-J). The absence of lymphatic valves was validated by immunostaining for LYVE-1 (Figure 3, M, N, S, and T) and integrin- $\alpha 9$ (Figure $3, K, L, Q$, and $R$ ), a marker for lymphatic valves. ${ }^{31}$ Consistently, there were integrin- $\alpha 9$ positive structures observed in the lymphatic vessels at the bottom side of ear skin in 


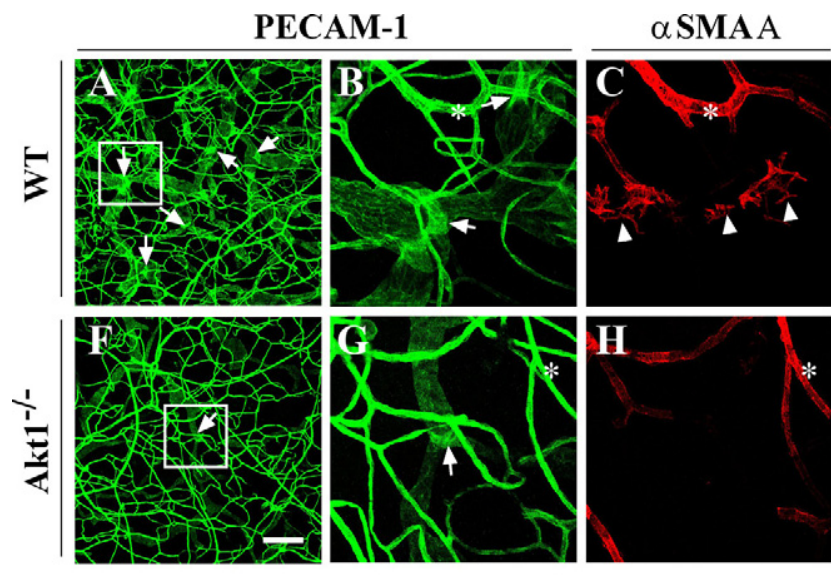

Ear bottom skin
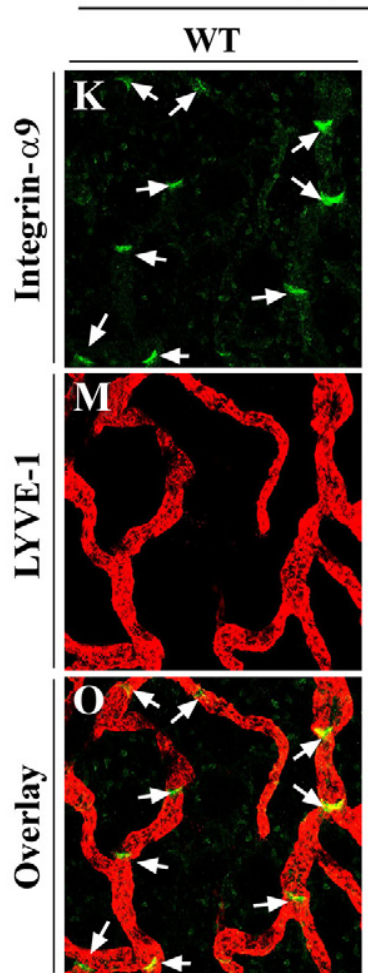
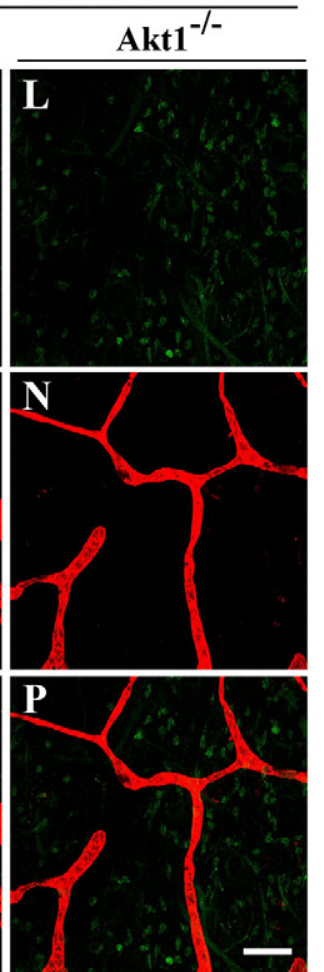

LYVE-1
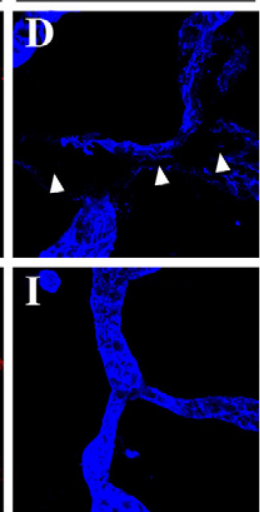

Ear upper skin
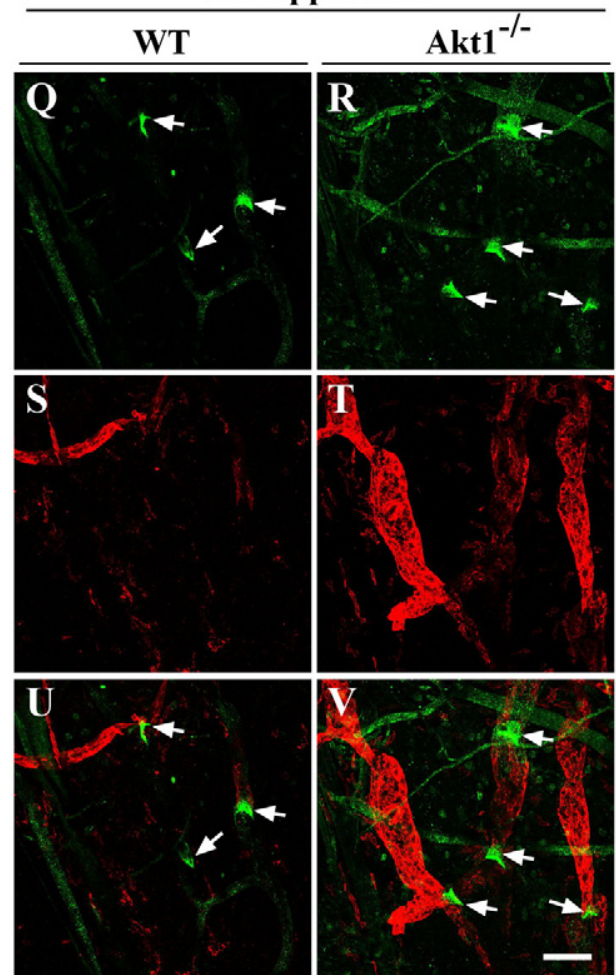

Figure 3. Defective lymphatic valve formation in Akt1-deficient mice. A-J: Whole-mount staining for PECAM-1, $\alpha$-smooth muscle actin (SMA), and LYVE-1 with ear skin of WT and $A k t 1^{-/-}$mice. B-E and $\mathbf{G}-\mathbf{J}$ : High-magnification view of boxed regions in $\mathbf{A}$ and $\mathbf{F}$, respectively. Arrows indicate lymphatic valves with strong PECAM-1 staining; arrowheads indicate regions in lymphatic vessels with SMC coverage, which are negative for LYVE-1 staining; asterisk indicates blood vessels with smooth muscle cell coverage. K-V: Whole-mount staining for LYVE-1 and integrin- $\alpha 9$ with ear skin of WT and Akt $1^{-/-}$mice. K-P: At the bottom side of ear skin adjacent to cartilage, integrin- $\alpha$ 9-positive lymphatic valves can be seen in WT (K and $\mathbf{O})$ but not $A k t 1^{-/-}$mice (L and $\left.\mathbf{P}\right)$. $\mathbf{Q}-\mathbf{V}$ : In both WT $(\mathbf{Q}$ and $\mathbf{U})$ and $A k t 1^{-1-}$ mice $(\mathbf{R}$ and $\mathbf{V})$, integrin- $\alpha$ 9-positive valves can be seen in the large collecting lymphatic vessels in the deep layer of skin tissues at the upper side of the ear. Arrows point to the valves. Scale bars: $200 \mu \mathrm{m}(\mathbf{F}) ; 50 \mu \mathrm{m}(\mathbf{J}) ; 100 \mu \mathrm{m}(\mathbf{P}$ and $\mathbf{V})$.

wild-type mice (Figure 3, $\mathrm{K}$ and $\mathrm{O}$, arrows), but these were rarely observed in $A k t 1^{-1-}$ mice (Figure 3, L and P). However, valves could be detected in large collecting lymphatics in the deep layer of tissues at the upper side of ear skin in both wild-type (Figure 3, Q and $U$, arrows) and Akt1-null mice (Figure 3, R and V, arrows).

\section{Defective Remodeling of Collecting Lymphatic Vessels in Akt1-Deficient Mice}

To examine the functionality of the lymphatic vessels in Akt1-null mice, FITC-dextran was injected intradermally for the visualization of lymphatic draining. The lymphatic network in Akt1-null mice was shown to have the draining function (Figure 4B) compared with that of wild-type mice (Figure 4A). However, there was an obvious delay with FITC-dextran draining as demonstrated in the tails of Akt1-null mice (Supplemental Figure 5, see http://ajp. amjpathol.org). There were no functional defects observed with collecting lymphatic vessels in Akt2- or Akt3null mice (data not shown). We also found that some regions of collecting lymphatic vessels appeared abnormally enlarged in Akt1-null mice (Figure 4B, arrowhead). The enlargement of collecting lymphatic vessels in 

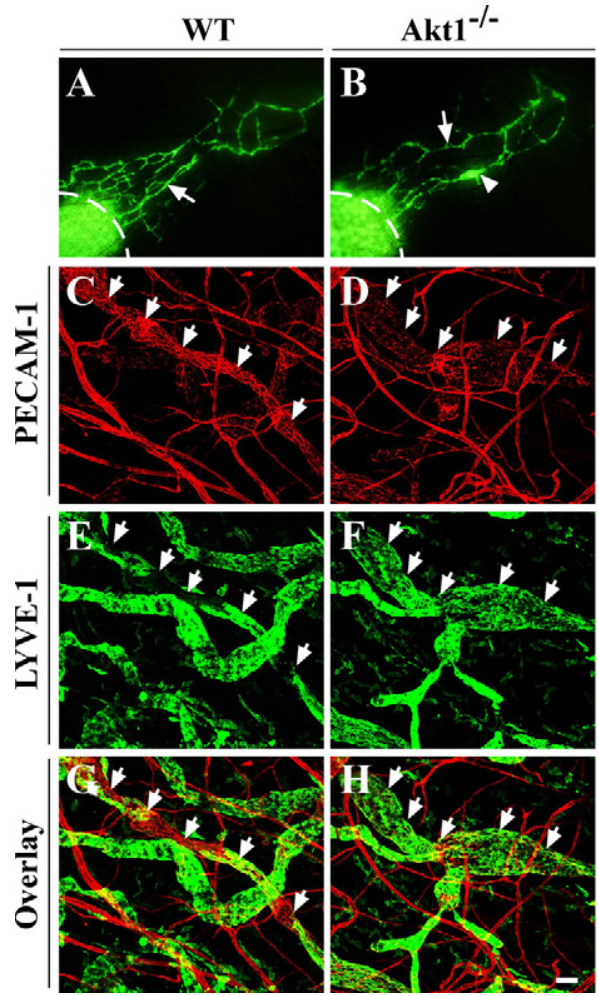
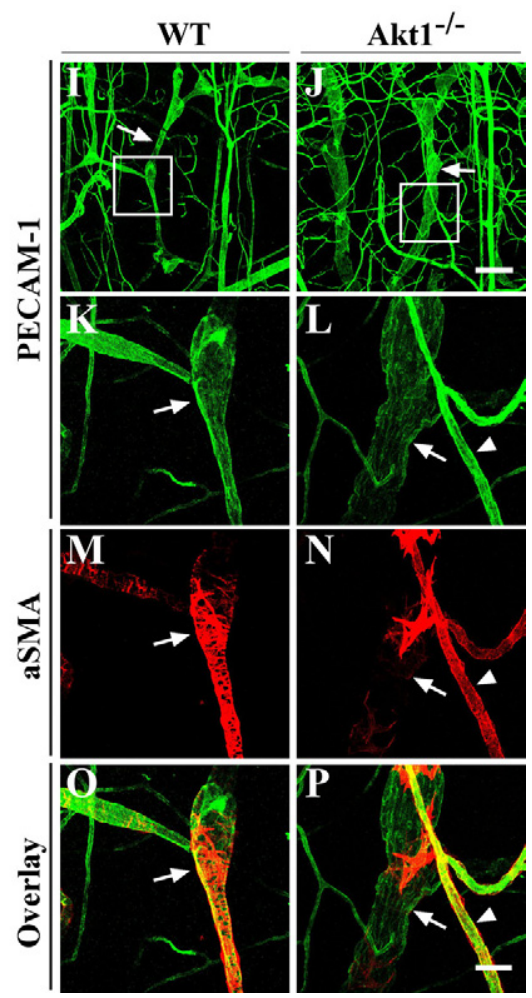

Figure 4. Defective smooth muscle cell coverage with collecting lymphatic vessels in Akt1 null mice. A and B: FITC-dextran microlymphangiography to examine the functionality of the collecting lymphatic vessels in ear skin of WT (A) and $A k t 1^{-1-}$ mice (B). Arrows in $\mathbf{A}$ and B point to functional collecting lymphatic vessels. Arrowhead in $\mathbf{B}$ points to an enlarged region of the collecting lymphatic vessels in Akt1-null mice. Dashed lines indicate the injection sites. C-H: Whole-mount immunostaining for PECAM-1 (red) and LYVE-1 (green) with ear skin of WT $(\mathbf{C}, \mathbf{E}$, and $\mathbf{G})$ and $A k t 1^{-/-}(\mathbf{D}, \mathbf{F}$, and H) mice. Arrows point to collecting lymphatic vessels. I-P: Whole-mount immunostaining for PECAM- 1 and $\alpha$-smooth muscle actin (aSMA) with ear skin from WT and $A k t 1^{-/-}$mice. K-P: High-magnification view of boxed regions in $\mathbf{I}$ and $\mathbf{J}$, respectively. Arrows indicate collecting lymphatic vessels with SMC coverage. Arrowheads indicate blood vessels with normal SMC coverage. Note that there is much sparser SMC coverage with collecting lymphatic vessels in $A k t^{-/-}$mice in comparison with that of the WT control. Scale bars: $50 \mu \mathrm{m}(\mathbf{H}) ; 200 \mu \mathrm{m}(\mathbf{J}) ; 50$ $\mu \mathrm{m}(\mathbf{P})$.
Akt1 ${ }^{-1-}$ mice was further confirmed by whole-mount immunostaining of ear skin for PECAM-1 and LYVE-1 (Figure $4, D, F$, and $H$, arrows), and collecting lymphatic vessels of wild-type mice are shown as controls in Figure 4, C, E, and G (arrows). The enlargement of collecting lymphatics was accompanied by a significant increase in lymphatic endothelial cell numbers (WT: $16.8 \pm 1.7$ cells/ $100 \mu \mathrm{m}$ lymphatic vessel; Akt1 ${ }^{-1-}: 25.3 \pm 5.9$ cells/100 $\mu \mathrm{m}$ lymphatic vessel, mean $\pm \mathrm{SD} ; n=4$ for each group; $P<0.05)$. This may result from the lack of contact inhibition of endothelial cell proliferation by vascular smooth muscle cells.

Further analysis by immunostaining for $\alpha$-smooth muscle actin showed that there was much sparser smooth muscle cell coverage with collecting lymphatics in Akt1deficient mice (Figure 4, J, L, N and P, arrows) than that in wild-type mice. Note that there was dense coating of smooth muscle cells in large collecting lymphatics except in the valve region in wild-type mice (Figure 4, I, K, $\mathrm{M}$ and $\mathrm{O}$, arrows). There were no obvious defects with SMC investment with blood vessels in Akt1-null mice (Figure 4, L, N, and P, arrowhead).

\section{Induction of Lymphangiogenesis by VEGF-C in Adult Mice Lacking Akt1}

We further analyzed the expression of Akt isoforms in lymphatic endothelial cells and activation of Akt by VEGF-C stimulation. In cultured human lymphatic endothelial cells, all three Akt isoforms can be detected at the mRNA level by RT-PCR analysis (data not shown). Treatment with VEGF-C induced an increase of Akt phosphorylation in lymphatic endothelial cells (Figure 5A).
To investigate whether the loss of Akt would have any effect on lymphangiogenesis in adults, mice were treated with VEGF-C delivered via adenoviral vector. Recombinant adenoviruses overexpressing human VEGF-C and GFP (AdVEGF-C/GFP) were examined for VEGF-C expression by Western blot analysis (Figure 5B), and GFP expression was confirmed under a fluorescence microscope (Figure 5C). Induction of lymphangiogenesis by AdVEGF-C/GFP in vivo was analyzed by whole-mount immunostaining of mouse ear skin for LYVE-1 after the administration of recombinant adenoviruses via subcutaneous injection. VEGF-C induced numerous lymphatic sprouts by day 4 (Figure 5, D-G and I-L, arrowhead), and massive lymphatic vessel growth by day 7 (Figure $5, \mathrm{H}$ and $\mathrm{M})$, after adenoviral transduction in both Akt1-null (Figure 5, I-M) and wild-type mice (Figure 5, D-H). It is noteworthy that there are more $\mathrm{GFP}^{+}$lymphatic endothelial cells in the Akt1-null mice (Figure 5, J-L, arrows) after AdVEGF-C/GFP treatment. This result suggests that there may be more adenoviruses retained in the skin lymphatic vessels of Akt1-null mice, resulting in increased adenoviral transduction of LECs. This finding supports the above observation (Supplemental Figure 5, see http://ajp. amjpathol.org) that the lymphatic draining function in $A k t 1^{-1-}$ mice is not as efficient as that of wild-type controls.

\section{Detection of Lymphatic Vessels in Akt Compound Knockout Mice}

To further investigate the compensatory role of Akt isoforms in lymphatic development, we analyzed lymphatic vessels in Akt compound knockout mice. Mice with de- 


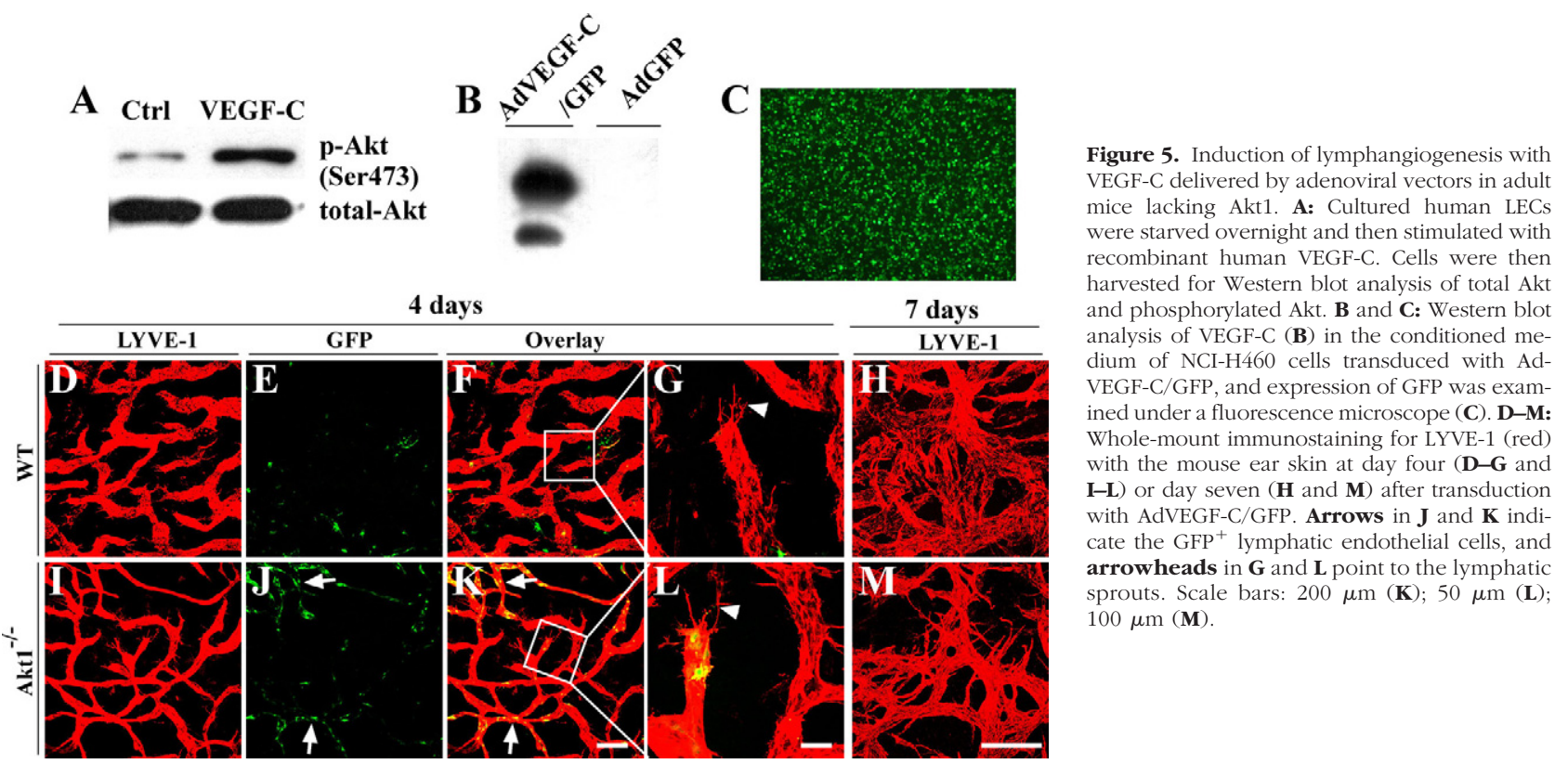

letion of both Akt2 and Akt3 (Akt2 $\left.{ }^{-/-} / A_{k t 3^{-/-}}\right)$survived well, and there were no obvious defects in the formation of the lymphatic network (Figure 6, A and C). Because mice with deletion of both Akt1 and Akt3 $\left(\right.$ Akt $^{-1-}$ ) $A k t 3^{-/-}$) are embryonic lethal before the emergence of lymphatic vessels, ${ }^{32}$ we analyzed mice homozygous for Akt1 deletion and heterozygous for Akt3 deletion $\left(A k t 1^{-/-} / A k t 3^{+/-}\right)$. Consistent with the phenotype of Akt1-null mice, the lymphatic capillary size was less than that of wild-type control (Figure 6, B and D), and there was no obvious difference between $\mathrm{Akt} 1^{-/-} / \mathrm{Akt}^{+/-}$and Akt1 ${ }^{-1-}$ mice. Lymphatic vessels could be detected in the skin of $A k t 1^{-/-} / A k t 2^{-1-}$ mice at postnatal day 1 (Figure $6 \mathrm{E})$, although they died shortly after birth, ${ }^{33}$ and skin tissues from $\mathrm{Akt1}^{+/-} / \mathrm{Akt2}^{+/-}$mice were used as control (Figure 6F). The results suggest that Akt1 is the major player in lymphatic development, whereas the Akt2 or Akt3 isoform can partially compensate for its loss during lymphatic development, as summarized in the schematic illustration (Figure 6G).

\section{Discussion}

In this study we have investigated the role of Akt in lymphatic development. We show that lymphangiogenesis occurred in mice null for Akt1, Akt2, or Akt3 during embryonic development and also in adult mice when induced by VEGF-C. However, loss of Akt1 led to reduced size in lymphatic capillary vessels and defects in smooth muscle cell coverage with collecting lymphatic vessels and valve development, whereas there was no obvious abnormality observed in mice with deletion of either Akt2 or Akt3 or both Akt2 and Akt3. This finding indicates that despite the partial compensatory role of Akt isoforms in lymphatic development, Akt1 is the most required isoform in lymphangiogenesis.
In mammals, three Akt genes exist, and they compensate for each other in a variety of biological functions because of their high sequence identity and ubiquitous expression. ${ }^{32,34-38}$ Consistently, we have found that lymphatic vessels could be detected in mice with genetic deletion of a single Akt isoform or with combined deficiency of Akt isoforms. There were no obvious defects with the lymphatic network observed in $A k t 2^{-1-} / A k t 3^{-/-}$ mice. However, abnormalities in lymphatic formation were observed when Akt1 is absent. The diameter of capillary lymphatic vessels is significantly less in $A k t 1^{-1-}$ mice than that in wild-type controls. The findings indicate that Akt1 alone is sufficient for maintaining lymphatic development, whereas Akt2 or Akt3 can only partially compensate for its loss. Akt1 has been shown to be the main isoform in blood vascular endothelial cells. ${ }^{22}$ The dominant role of Akt1 in lymphatic vessel growth suggests that Akt1 may also be the major isoform in lymphatic endothelial cells although transcripts for three Akt genes can be detected in LECs by RT-PCR (data not shown). It is therefore likely that the survival signal for LECs may be attenuated in Akt1-null mice, which leads to the reduced LEC number and capillary size. However, apoptotic lymphatic endothelial cells could hardly be detected by terminal deoxynucleotidyl transferase dUTP nick-end labeling staining in both wild-type and Akt1-null mice (data not shown). There was only a slight decrease in lymphatic endothelial proliferation by BrdU labeling in Akt1-null mice, and the difference was not statistically significant compared with that in wild-type controls (Supplemental Figure 2, see http://ajp.amjpathol.org). Although eNOS has been shown to be the immediate signaling molecule downstream of Akt, ${ }^{39,40}$ loss of Akt1, Akt2, or Akt3 alone does not seem to have a strong effect on eNOS phosphorylation. We show that phospho-eNOS could be detected in lymphatic endothelial cells of 

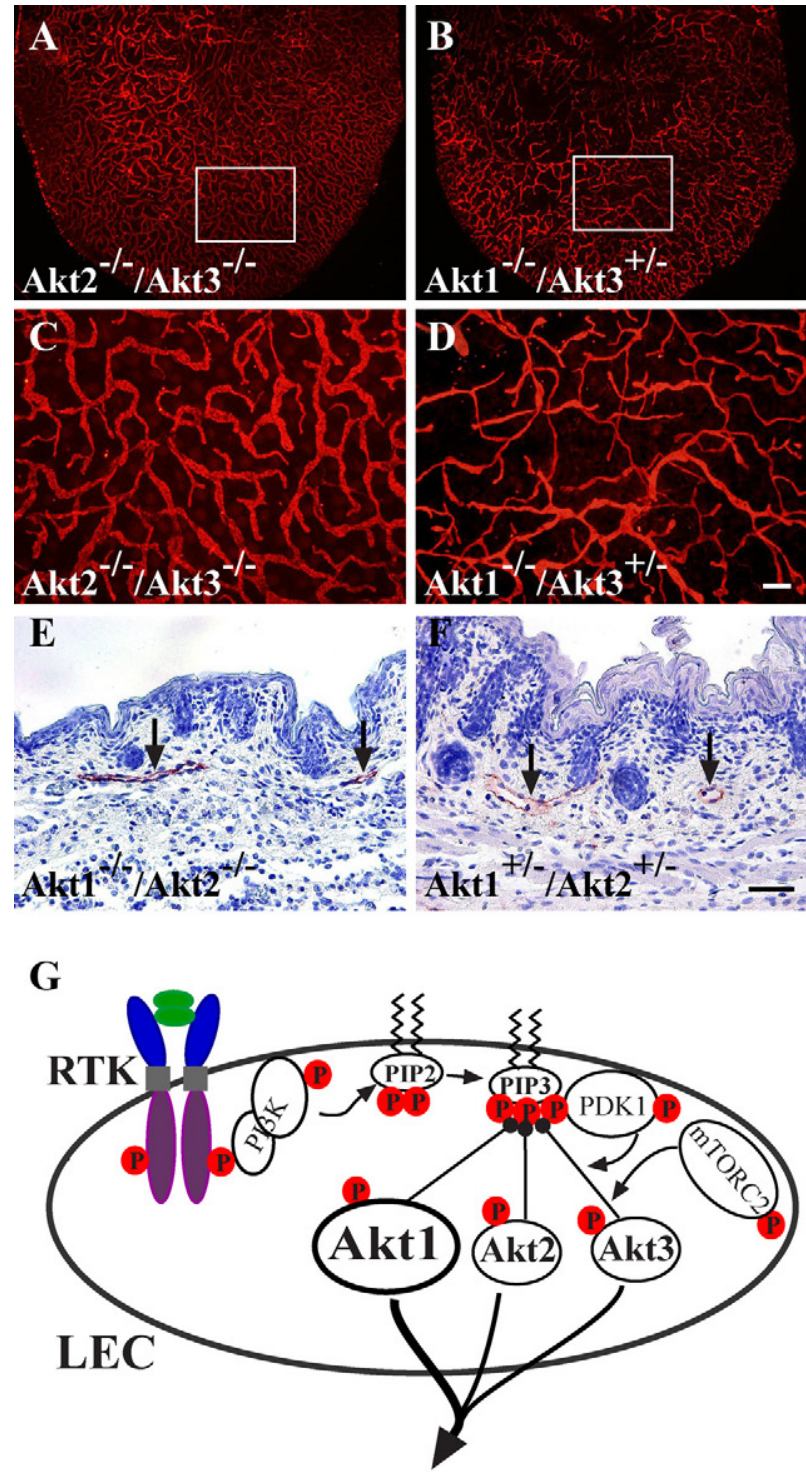

\section{Lymphatic development}

Capillary lymphatic formation Collecting lymphatic remodeling Lymphatic valve development

Figure 6. Compensatory roles of Akt isoforms in lymphatic development A-D: Whole-mount immunostaining for LYVE-1 with ear skin of compound knockout mice $\left(A k t 2^{-/-} / A k t 3^{-1-}[\mathbf{A}]\right.$ and $\left.A k t 1^{-/-} / A k t 3^{+/-}[\mathbf{B}]\right)$. C and $\mathbf{D}$ : High-magnification view of the boxed regions in $\mathbf{A}$ and $\mathbf{B}$, respectively. $\mathbf{E}$ and F: Immunohistochemical staining for LYVE-1 with skin sections from $A k t 1^{-/-} / A k t 2^{-/-}(\mathbf{E})$ and $A k t 1^{+/-} / A k t 2^{+/-}(\mathbf{F})$ at postnatal day one. Arrows point to lymphatic vessels. G: Schematic illustration to summarize the roles of Akt in lymphatic development. In LECs, three Akt isoforms are expressed, and Akt can be activated downstream of various receptor tyrosine kinases (RTK). Akt1 is the most required isoform in lymphatic development although Akt 2 or Akt 3 can partially compensate for its absence. Scale bars: $200 \mu \mathrm{m}$ (D); $50 \mu \mathrm{m}(\mathbf{F})$

Akt1 ${ }^{-1-}$ mice and other Akt isoform-deficient mice, and there was no obvious difference in the level of phosphorylated eNOS by immunostaining between Akt1-null and wild-type mice (Supplemental Figure 3, see http://ajp. amjpathol.org). This may be due to the compensatory mechanisms by the remaining Akt isoforms and/or other protein kinases such as protein kinase $A{ }^{22,41}$ Compen- sation of Akt isoforms in lymphatic growth was also validated by the occurrence of lymphangiogenesis on VEGF-C induction in adult Akt1-null mice. Furthermore, Akt has the potential to phosphorylate multiple substrates. ${ }^{42}$ It is possible that several molecular pathways are disrupted in lymphatic endothelial cells of Akt1-null mice, which altogether contributes to the defects observed with lymphatic development. The details about altered downstream signals in lymphatic endothelial cells in the absence of Akt1 or other Akt isoforms are yet to be investigated.

In addition to the decrease in lymphatic capillary size, there were also remodeling defects with collecting lymphatic vessels. We observed that the skin collecting lymphatic vessels of Akt1-null mice were abnormally enlarged. Immunohistochemical analysis showed that there was insufficient coverage of collecting lymphatic vessels by smooth muscle cells in Akt1-deficient mice. Impaired SMC recruitment to the collecting lymphatic vessels has been shown in Ang2-null mice. ${ }^{43}$ On the other hand, ephrinB2 has been shown to be expressed by collecting lymphatic endothelium, and the abnormal coverage of SMC with capillary lymphatics has been shown in ephrinB2-mutant mice with loss of the C-terminal PDZ interaction site. ${ }^{44}$ An increase in SMC coverage with lymphatic vessels has also been shown in Foxc2-deficient mice, because of the increased platelet-derived growth factor-B expression by lymphatic endothelial cells. ${ }^{45}$ It is not clear how these distinct signaling pathways coordinate to regulate lymphatic vessel remodeling and maturation. However, Akt has been shown to be an important mediator downstream of various receptor protein kinases such as Tie2, platelet-derived growth factor receptor- $\beta$, and EphB4, which are critically required for vascular remodeling and maturation involving vascular differentiation and mural cell recruitment and its interaction with endothelial cells for stabilizing vasculature. ${ }^{15,18,46-50}$ This finding suggests that Akt plays an important role in mediating the signals for the remodeling of primary lymphatic vessels into a mature network and that defects with lymphatic remodeling may be due to the insufficient recruitment of SMCs or poor interactions between SMCs and LECS.

Interestingly, in this study, we also observed that lymphatic valves are rarely seen in the small collecting lymphatic vessels but are present in large ones in $A k t 1^{-1-}$ mice. Lymphatic valves are tiny semilunar structures, which are important for preventing lymph backflow during their contraction. Formation of vascular valves involves several important cellular events including endothelial to mesenchymal transformation followed by cell proliferative expansion, migration, and remodeling into valve leaflets. ${ }^{51}$ So far there is little understanding about the molecular regulation of lymphatic valve development. Defective development of lymphatic valves has also been reported in mice with genetic deletion of the Foxc2 gene, ${ }^{45}$ in ephrinB2 mutant mice, ${ }^{44}$ in mice with endothelial cellspecific deletion of Itga9, ${ }^{31}$ and in Pik3r1-deficient mice. ${ }^{24}$ Based on this study and findings of other researchers, it seems that the phosphoinositide-3 kinase-Akt pathway plays an important role in lymphatic valve development. The 
detailed cellular and molecular mechanisms underlying this process require further investigation.

Finally, there was no obvious change in blood vessel size by whole-mount immunostaining for PECAM1 with ear skin (Supplemental Figure 2, see http://ajp.amjpathol. org) and internal organs such as retina (data not shown) of Akt1-null mice, although the blood vessel basement membrane was reported to be thinner with reduced laminin content. ${ }^{22}$ This finding is consistent with studies by other researchers showing that Akt1 is not essential for blood vascular growth during embryonic development because Akt1-null mice are viable, but rather it has an important role during pathological angiogenesis. ${ }^{22,52-54}$ Our findings are also in agreement with the observation that there is no abnormal blood vessel growth observed in Pik3r1-null mice despite defective lymphatic development. ${ }^{24}$ In addition to the difference in molecular profiles between blood vascular and lymphatic endothelial cells, ${ }^{55,56}$ the distinct phenotype in response to the loss of Akt1 could also be related to the structural difference between blood vascular and lymphatic capillaries. In blood vessels, there is continuous basement membrane and also supporting pericytes, whereas lymphatic capillaries do not have supporting cells and the basement membrane is discontinuous. The LECs may be more sensitive to the Akt-mediated signaling for survival than blood vascular endothelial cells.

To summarize, loss of Akt1 led to the reduced size of lymphatic capillaries and defects in the maturation of collecting lymphatic vessels and valve development, and Akt2 or Akt3 could partially compensate for its loss during lymphatic development. The distinct requirement of Akt isoforms in vascular development may reflect their differential expression levels in endothelial cells. However, it is also possible that there may exist Akt isoform-specific substrates in different types of cells. Further investigation in this direction would help us understand the differential requirement of Akt in blood vascular and lymphatic development.

\section{Acknowledgments}

We thank Yanlan Cao, Dong Liang (Nanjing University), and the staff of the MARC Animal Facility (Nanjing University) for excellent technical assistance and help with animal work. The Friedrich Miescher Institute for biomedical research is part of the Novartis Research Foundation.

\section{References}

1. Adams $\mathrm{RH}$, Alitalo K: Molecular regulation of angiogenesis and lymphangiogenesis. Nat Rev Mol Cell Biol 2007, 8:464-478

2. Alitalo K, Tammela T, Petrova TV: Lymphangiogenesis in development and human disease. Nature 2005, 438:946-953

3. Oliver G, Detmar M: The rediscovery of the lymphatic system: old and new insights into the development and biological function of the Iymphatic vasculature. Genes Dev 2002, 16:773-783

4. He Y, Karpanen T, Alitalo K: Role of lymphangiogenic factors in tumor metastasis. Biochim Biophys Acta 2004, 1654:3-12

5. Cueni LN, Detmar M: New insights into the molecular control of the lymphatic vascular system and its role in disease. J Invest Dermatol 2006, 126:2167-2177

6. Baluk P, McDonald DM: Markers for microscopic imaging of lymphangiogenesis and angiogenesis. Ann NY Acad Sci 2008, 1131:1-12

7. Wigle JT, Oliver G: Prox1 function is required for the development of the murine lymphatic system. Cell 1999, 98:769-778

8. Wigle JT, Harvey N, Detmar M, Lagutina I, Grosveld G, Gunn MD, Jackson DG, Oliver G: An essential role for Prox1 in the induction of the lymphatic endothelial cell phenotype. EMBO J 2002, 21:1505-1513

9. Françcois M, Caprini A, Hosking B, Orsenigo F, Wilhelm D, Browne C Paavonen K, Karnezis T, Shayan R, Downes M, Davidson T, Tutt D, Cheah KS, Stacker SA, Muscat GE, Achen MG, Dejana E, Koopman $P$ : Sox18 induces development of the lymphatic vasculature in mice. Nature 2008, 456:643-647

10. Mäkinen T, Jussila L, Veikkola T, Karpanen T, Kettunen MI, Pulkkanen KJ, Kauppinen R, Jackson DG, Kubo H, Nishikawa S, Yla-Herttuala S, Alitalo K: Inhibition of lymphangiogenesis with resulting lymphedema in transgenic mice expressing soluble VEGF receptor-3. Nat Med 2001, 7:199-205

11. Karkkainen MJ, Haiko P, Sainio K, Partanen J, Taipale J, Petrova TV, Jeltsch M, Jackson DG, Talikka M, Rauvala H, Betsholtz C, Alitalo K: Vascular endothelial growth factor $C$ is required for sprouting of the first lymphatic vessels from embryonic veins. Nat Immunol 2004, 5:74-80

12. Dummler $B$, Hemmings BA: Physiological roles of $P K B / A k t$ isoforms in development and disease. Biochem Soc Trans 2007, 35:231-235

13. Shiojima I, Walsh K: Regulation of cardiac growth and coronary angiogenesis by the Akt/PKB signaling pathway. Genes Dev 2006, 20:3347-3365

14. Brazil DP, Yang ZZ, Hemmings BA: Advances in protein kinase B signalling: aKTion on multiple fronts. Trends Biochem Sci 2004 , 29:233-242

15. Kim I, Kim HG, So JN, Kim JH, Kwak HJ, Koh GY: Angiopoietin-1 regulates endothelial cell survival through the phosphatidylinositol 3'-kinase/Akt signal transduction pathway. Circ Res 2000, 86:24-29

16. Gerber HP, McMurtrey A, Kowalski J, Yan M, Keyt BA, Dixit V, Ferrara $\mathrm{N}$ : Vascular endothelial growth factor regulates endothelial cell survival through the phosphatidylinositol 3'-kinase/Akt signal transduction pathway. Requirement for Flk-1/KDR activation, J Biol Chem 1998, 273:30336-30343

17. Fujio $\mathrm{Y}$, Walsh $\mathrm{K}$ : Akt mediates cytoprotection of endothelial cells by vascular endothelial growth factor in an anchorage-dependent manner. J Biol Chem 1999, 274:16349-16354

18. Papapetropoulos A, Fulton D, Mahboubi K, Kalb RG, O'Connor DS, Li F, Altieri DC, Sessa WC: Angiopoietin-1 inhibits endothelial cell apoptosis via the Akt/survivin pathway. J Biol Chem 2000, 275:91029105

19. Chan J, Bayliss PE, Wood JM, Roberts TM: Dissection of angiogenic signaling in zebrafish using a chemical genetic approach. Cancer Cell 2002, 1:257-267

20. Jiang BH, Zheng JZ, Aoki M, Vogt PK: Phosphatidylinositol 3-kinase signaling mediates angiogenesis and expression of vascular endothelial growth factor in endothelial cells, Proc Natl Acad Sci USA 2000, 97:1749-1753

21. Shiojima I, Walsh K: Role of Akt signaling in vascular homeostasis and angiogenesis. Circ Res 2002, 90:1243-1250

22. Chen J, Somanath PR, Razorenova O, Chen WS, Hay N, Bornstein P, Byzova TV: Akt1 regulates pathological angiogenesis, vascular maturation and permeability in vivo. Nat Med 2005, 11:1188-1196

23. Fruman DA, Mauvais-Jarvis F, Pollard DA, Yballe CM, Brazil D, Bronson RT, Kahn CR, Cantley LC: Hypoglycaemia, liver necrosis and perinatal death in mice lacking all isoforms of phosphoinositide 3-kinase p85 $\alpha$. Nat Genet 2000, 26:379-382

24. Mouta-Bellum C, Kirov A, Miceli-Libby L, Mancini ML, Petrova TV, Liaw L, Prudovsky I, Thorpe PE, Miura N, Cantley LC, Alitalo K, Fruman DA, Vary CP: Organ-specific lymphangiectasia, arrested lymphatic sprouting, and maturation defects resulting from gene-targeting of the PI3K regulatory isoforms p85 $\alpha$, p55 $\alpha$, and p50 $\alpha$. Dev Dyn 2009, 238:2670-2679

25. Yang ZZ, Tschopp O, Hemmings-Mieszczak M, Feng J, Brodbeck D, Perentes E, Hemmings BA: Protein kinase $\mathrm{B} \alpha /$ Akt1 regulates placental development and fetal growth. J Biol Chem 2003, 278:3212432131 
26. Tschopp O, Yang ZZ, Brodbeck D, Dummler BA, Hemmings-Mieszczak M, Watanabe T, Michaelis T, Frahm J, Hemmings BA: Essential role of protein kinase $\mathrm{B} \gamma(\mathrm{PKB} \gamma / \mathrm{Akt} 3)$ in postnatal brain development but not in glucose homeostasis. Development 2005, 132:2943-2954

27. Dummler B, Tschopp O, Hynx D, Yang ZZ, Dirnhofer S, Hemmings BA: Life with a single isoform of Akt: mice lacking Akt2 and Akt3 are viable but display impaired glucose homeostasis and growth deficiencies. Mol Cell Biol 2006, 26:8042-8051

28. Lee S, Kang J, Yoo J, Ganesan SK, Cook SC, Aguilar B, Ramu S, Lee J, Hong YK: Prox1 physically and functionally interacts with COUPTFIl to specify lymphatic endothelial cell fate. Blood 2009, 113: 1856-1859

29. Tammela T, He Y, Lyytikka J, Jeltsch M, Markkanen J, Pajusola K, Yla-Herttuala S, Alitalo K: Distinct architecture of lymphatic vessels induced by chimeric vascular endothelial growth factor-C/vascular endothelial growth factor heparin-binding domain fusion proteins. Circ Res 2007, 100:1468-1475

30. Banerji S, Ni J, Wang SX, Clasper S, Su J, Tammi R, Jones M, Jackson DG: LYVE-1, a new homologue of the CD44 glycoprotein, is a lymphspecific receptor for hyaluronan. J Cell Biol 1999, 144:789-801

31. Bazigou E, Xie S, Chen C, Weston A, Miura N, Sorokin L, Adams R, Muro AF, Sheppard D, Makinen T: Integrin- $\alpha 9$ is required for fibronectin matrix assembly during lymphatic valve morphogenesis. Dev Cell 2009, 17:175-186

32. Yang ZZ, Tschopp O, Di-Poi N, Bruder E, Baudry A, Dummler B, Wahli W, Hemmings BA: Dosage-dependent effects of Akt1/protein kinase $\mathrm{B} \alpha(\mathrm{PKB} \alpha)$ and $\mathrm{Akt} 3 / \mathrm{PKB} \gamma$ on thymus, skin, and cardiovascular and nervous system development in mice. Mol Cell Biol 2005, 25: 10407-10418

33. Peng XD, Xu PZ, Chen ML, Hahn-Windgassen A, Skeen J, Jacobs J, Sundararajan D, Chen WS, Crawford SE, Coleman KG, Hay N: Dwarfism, impaired skin development, skeletal muscle atrophy, delayed bone development, and impeded adipogenesis in mice lacking Akt1 and Akt2. Genes Dev 2003, 17:1352-1365

34. Jones PF, Jakubowicz T, Hemmings BA: Molecular cloning of a second form of rac protein kinase. Cell Regul 1991, 2:1001-1009

35. Altomare DA, Guo K, Cheng JQ, Sonoda G, Walsh K, Testa JR: Cloning, chromosomal localization and expression analysis of the mouse Akt2 oncogene. Oncogene 1995, 11:1055-1060

36. Brodbeck D, Cron P, Hemmings BA: A human protein kinase B $\gamma$ with regulatory phosphorylation sites in the activation loop and in the C-terminal hydrophobic domain. J Biol Chem 1999, 274:9133-9136

37. Nakatani K, Sakaue H, Thompson DA, Weigel RJ, Roth RA: Identification of a human Akt3 (protein kinase B $\gamma$ ) which contains the regulatory serine phosphorylation site. Biochem Biophys Res Commun 1999, 257:906-910

38. Bellacosa A, Franke TF, Gonzalez-Portal ME, Datta K, Taguchi T, Gardner J, Cheng JQ, Testa JR, Tsichlis PN: Structure, expression and chromosomal mapping of c-akt: relationship to v-akt and its implications. Oncogene 1993, 8:745-754

39. Dimmeler S, Fleming I, Fisslthaler B, Hermann C, Busse R, Zeiher AM: Activation of nitric oxide synthase in endothelial cells by Akt-dependent phosphorylation. Nature 1999, 399:601-605

40. Fulton D, Gratton JP, McCabe TJ, Fontana J, Fujio Y, Walsh K, Franke TF, Papapetropoulos A, Sessa WC: Regulation of endothelium-derived nitric oxide production by the protein kinase Akt. Nature 1999, 399:597-601

41. Dixit M, Loot AE, Mohamed A, Fisslthaler B, Boulanger CM, Ceacareanu B, Hassid A, Busse R, Fleming I: Gab1, SHP2, and protein kinase A are crucial for the activation of the endothelial NO synthase by fluid shear stress, Circ Res 2005, 97:1236-1244

42. Lawlor MA, Alessi DR: PKB/Akt: a key mediator of cell proliferation, survival and insulin responses?. J Cell Sci 2001, 114:2903-2910

43. Gale N, Thurston G, Hackett S, Renard R, Wang Q, McClain J, Martin C, Witte C, Witte M, Jackson D, Suri C, Campochiaro P, Wiegand S, Yancopoulos G: Angiopoietin-2 is required for postnatal angiogenesis and lymphatic patterning, and only the latter role is rescued by angiopoietin-1. Dev Cell 2002, 3:411-423

44. Mäkinen T, Adams RH, Bailey J, Lu Q, Ziemiecki A, Alitalo K, Klein R, Wilkinson GA: PDZ interaction site in ephrinB2 is required for the remodeling of lymphatic vasculature. Genes Dev 2005, 19:397-410

45. Petrova TV, Karpanen T, Norrmen C, Mellor R, Tamakoshi T, Finegold D, Ferrell R, Kerjaschki D, Mortimer P, Yla-Herttuala S, Miura N, Alitalo $\mathrm{K}$ : Defective valves and abnormal mural cell recruitment underlie lymphatic vascular failure in lymphedema distichiasis. Nat Med 2004, 10:974-981

46. Hellström M, Kalen M, Lindahl P, Abramsson A, Betsholtz C: Role of PDGF-B and PDGFR- $\beta$ in recruitment of vascular smooth muscle cells and pericytes during embryonic blood vessel formation in the mouse. Development 1999, 126:3047-3055

47. Suri C, Jones PF, Patan S, Bartunkova S, Maisonpierre PC, Davis S, Sato TN, Yancopoulos GD: Requisite role of angiopoietin-1, a ligand for the TIE2 receptor, during embryonic angiogenesis. Cell 1996, $87: 1171-1180$

48. Kumar SR, Singh J, Xia G, Krasnoperov V, Hassanieh L, Ley EJ, Scehnet J, Kumar NG, Hawes D, Press MF, Weaver FA, Gill PS: Receptor tyrosine kinase EphB4 is a survival factor in breast cancer. Am J Pathol 2006, 169:279-293

49. Adams RH, Wilkinson GA, Weiss C, Diella F, Gale NW, Deutsch U, Risau W, Klein R: Roles of ephrinB ligands and EphB receptors in cardiovascular development: demarcation of arterial/venous domains, vascular morphogenesis, and sprouting angiogenesis. Genes Dev 1999, 13:295-306

50. Wang HU, Chen ZF, Anderson DJ: Molecular distinction and angiogenic interaction between embryonic arteries and veins revealed by ephrin-B2 and its receptor Eph-B4. Cell 1998, 93:741-753

51. Shworak NW: Angiogenic modulators in valve development and disease: does valvular disease recapitulate developmental signaling pathways?. Curr Opin Cardiol 2004, 19:140-146

52. Ackah E, Yu J, Zoellner S, Iwakiri Y, Skurk C, Shibata R, Ouchi N, Easton RM, Galasso G, Birnbaum MJ, Walsh K, Sessa WC: Akt1/ protein kinase $B \beta$ is critical for ischemic and VEGF-mediated angiogenesis. J Clin Invest 2005, 115:2119-2127

53. Cho H, Thorvaldsen JL, Chu Q, Feng F, Birnbaum MJ: Akt1/PKB $\alpha$ is required for normal growth but dispensable for maintenance of glucose homeostasis in mice. J Biol Chem 2001, 276:38349-38352

54. Chen WS, Xu PZ, Gottlob K, Chen ML, Sokol K, Shiyanova T, Roninson I, Weng W, Suzuki R, Tobe K, Kadowaki T, Hay N: Growth retardation and increased apoptosis in mice with homozygous disruption of the Akt1 gene. Genes Dev 2001, 15:2203-2208

55. Petrova TV, Makinen T, Makela TP, Saarela J, Virtanen I, Ferrell RE, Finegold DN, Kerjaschki D, Yla-Herttuala S, Alitalo K: Lymphatic endothelial reprogramming of vascular endothelial cells by the Prox-1 homeobox transcription factor. EMBO J 2002, 21:4593-4599

56. Hirakawa S, Hong YK, Harvey N, Schacht V, Matsuda K, Libermann $\mathrm{T}$, Detmar M: Identification of vascular lineage-specific genes by transcriptional profiling of isolated blood vascular and lymphatic endothelial cells. Am J Pathol 2003, 162:575-586 